\title{
Sayyid Mawdudi's Contribution towards Islamic Revivalism in the Contemporary Islamic Political thought
}

\author{
Ibrahim Suleiman ${ }^{1} \&$ Ya’u Idris Gadau ${ }^{1}$
}

\author{
${ }^{1}$ Department of Political Science, Bauchi State University, Gadau, Nigeria \\ Correspondence: Department of Political Science, Bauchi State University, Gadau, Nigeria. Email: \\ isuleiman@basug.edu.ng. Tel: +2348060287718
}

Received: January 20, 2018

Accepted: January 30, 2018

Online Published: March 8, 2018

\begin{abstract}
This paper discussed the role and ideas of Sheikh Mawdudi in religion and politics in India and later Pakistan, Lahore. It is very paramount that Islamic scholars are considered to be relevant in moulding the minds of Muslims Ummah towards adherence to their religion and participation in politics and electoral process. Therefore, this article highlights the major contributions made by Mawdudi and outlines his role in terms of revivalism during his life-time and beyond. This is accomplished by investigating his major works and his teachings especially in shaping participation in political circle so as to ensure that Muslims are participated in the political and electoral process in India and Pakistan. In his political thought, Sheikh Mawdudi believed strongly in the formation of Islamic state and participation of Muslims in politics and governance as against the other views of anti-democratic arguments. His major concern is to encourage Muslims Ummah to adhere to the teaching of Islam and participate in all government activities in order to protect the interest of their religion considering the diverse nature of these countries. Therefore, assessing the role played by Mawdudi will significantly improve our understanding of Islamization movement towards determining social reality, justice and equity along Islamic ethics and values.
\end{abstract}

Keywords: Islamic Revivalism, Islamic Political Thought, Political Participation, Social Justice, Democracy, Welfarism and Social Responsibilities.

\section{Introduction}

The world of the 20th Century witnessed some great scholars who had contributedextensively for the promotion of Islam and to establish it as a complete code of life.Mawdudi had secured a respectable place in it. He had shown in practical terms how Islam could be pressed into the service of the modern people and their day-to-day problems. Mawdudi started his mission at a time when all Muslim countries were under director indirect subjugation of the Western colonial rulers. The call he made in 1932 as a cry in wilderness was well received by the like-minded Muslims of the world. He founded Jama'at-Islami in 1941 with the sole objective of Iqamat-i-din, or establishing Islam in every aspect of life. The branches of Jama at-Islami are now not confined in Pakistan alone, they are spread throughout the world. Most of the Islamic organizations regard him as a key figure of Islamic movement and benefit from his literature.Mawdudi was a man of versatile creativity.

Moreover, He showed in practical terms how Islam could be used today to solve the problems of Muslims in modern ages. It was his literature that provided the bases for Islamic political system, economic system, cultural system, social system and so on. Many of his contemporaries were doubtful that Islam could also provide constitutional guidelines. Mawdudi, not only highlighted the constitutional principles of the Qur'an, but also fought to establish it in Pakistan. The people came to realize that Islam is a complete way of life. This comprehension of Islam as a complete code of life, and straightforward expression earned him the hostility of 
many; while many others appreciated him and actively followed him. Some even accused him of claiming the position of Mujaddid or establishing a new sect of Mawdudism. He passed away without claiming any of such positions for him, or trying to establish a new sect. His life was rather dedicated to unite various sects under the banner of the Qur'an and Sunnah. Mawdudi's pen was prolific and forceful.

\section{Brief Historical Background of Mawdudi}

Imam Abu A'la Al-Mawdudi was born on 25th September, 1903 at Aurangabad, India, he received his early education at home from his parent. His father supervised him in Quran, hadith, sharia, Islamic languages and history. At the age of eight, he was admitted into a local school, and in 1916, was admitted into Darul-'Ulum College of Hyderabad for his matriculation studies. Mawdudi could hardly pass six months that his father suffered severe attack of paralysis and had to postpone studies attending his ailing father for about two years. Since then, Mawdudi had to struggle in life. His formal education came to a stopped because of serious financial difficulties.His stated his early career as journalist when he was 21 years, he became and editor of Al-Jamiah 1924-1927, the newspaper of India's Jamiyatul Ulama (association of Ulama).

In 1921, his financial condition improved, and resumed his studies that were postponed earlier. He studied Tafsir, Hadith, Usulul-Fiqh, English and many other subjects from the famous scholars of that time. He used to attend some of his teachers even before Fajr prayers as scheduled by the teachers. In 1928, he wrote his famousbook, a noble masterpiece on the subject of Islamic War, namely, Al-Jihad fi al-Islam, a book, which though written by Mawdudi in his 20s, acclaimed by great scholars like Iqbal.In 1932, he decided to run his own journal, namely Tarjumanul Qur'an as aMouthpiece for Islamic revivalism that he was cherishing since long. He invited the Muslims of the world and especially those of India to rise with the banner of Islam as did the earlier companions of the Prophet. It was through Tarjumanul Qur'an that he invited people, who were determined to dedicate their life for the establishment and promotion of Islam in every aspect of life, to participate in the formation of Jama`at-Islami. On $31^{\text {st }}$ August, 1941, Jama'atu- Islami was established with the active participation of 75 founding members.Mawdudi raised his voice to establish a separate land for Islam and Muslims and after independence in 1947 demanded immediate implementation of Islam in thenewly born state of Pakistan.

But the ruling authority did not listen to the demands of Mawdudi and Islamic people of the country. In 1953, 11th May, he was sentenced to death by the Marshal Law court of Pakistan because of writing a pamphlet on Qadiyani's. The Muslims protested world-wide to lift the sentence on Mawdudi, and urged the government to send him to other countries if his presence was not desired in Pakistan. Mawdudi was asked to appeal for Mercy, but he rejected to submit Mercy petition to the government. Finally, the ruling was changed to life imprisonment. Later the High Court set aside the life imprisonment and freed Mawdudi respectfully from the term of imprisonment. Mawdudi led the Jama at Islami with his effective leadership, and contributed in writing many books and articles on fundamental aspects of Islam and its contemporary application in various fields. The most important writing was his widely known Tafsir, Tahfim-ul-Qur'an, which took about 30 years to complete. Mawdudi suffered illness several times and in 1972 he appealed to the highest council of Jama at Islami to relieve him from the post of Amir of Jama`at, which was later approved by the Members of the Jama at. He was relieved and concentrated fully to complete Tafsir, which he did in the same year. A few years later, he fell seriously ill, and was taken to USA by his son who was working there in a hospital as a medical Doctor. He died on September 22, 1979 in Buffalo, USA. He was buried at his house in Lahore where he used to hold daily afternoon sessions with the people and used to answer all kind of questions.

3.The Political, Social, and Economic Circumstances That Led to the Emergence of Islamic Movement in India During Mawdudi's Time

Many circumstances contributed to the emergence of contemporary Islamic movements. These circumstances are 
as follows:-

\subsection{Reaction to the negative effects of the modernity}

Islamic movement emerged as a response to Western induced modern social and cultural changes that "threaten to undermine Islamic identity through the propagation of un-Islamic elements". Esposito, (1990) claims that the positive benefits of modernization benefited only a few, while the majority felt mainly its negative fallout rural migration and rapid urbanization, the breakdown of traditional family values, and a general climate of disillusionment and misery. Deukmejian, (1985) also stresses the negative social and economic effects of modernization which included the population explosion, the breakdown of traditional religious and social values, high unemployment, and the sharp inequalities in wealth distribution.

\subsection{Reaction to so-called western domination}

Colonialism brings about the Western cultural dominance which imposed secularization, dependence, and a division of life into separate secular and religious spheres. The famous Indian Islamic thinker Muhammad Iqbal (1877-1938) vividly expressed the commonly held view of the "insensitive multi-layered Western civilization" in its varied manifestations of capitalism, communism, secularism, and liberalism, challenging Islam of itsinherent vitality. In sharp contrast to the miserable present, he recreated the memories of Islam's past glorious golden age.

\subsection{Failure of Islamic liberalization and nation building}

Contemporary Islamic movement also came as a reaction to the failures of Islamic liberalism in the $19^{\text {th }}$ and $20^{\text {th }}$ centuries, as well as to the failures of nationalism and socialism after independence. Islamists compete both with the modernists, who accept a broad interpretation of Scripture and adopt some Western values, and with the secularist-liberals who argue for a democratic, pluralist state on the Western model. Islamists reject these worldviews and seek a return to the original sources of Islam, whilst claiming the right to re-interpret them (ijtihad) and reapply them to contemporary contexts (Ibid).

\subsection{Political and economic suppression of the Muslim countries}

The Arab defeat in the 1967 war against Israel, the secession of Bangladesh from Pakistan in 1971, the Lebanese civil war in the mid-1970s, the colonial domination of India by the British, and the Soviet invasion of Afghanistan in 1979 were promoters in the spread of Islamic movement especially in the $20^{\text {th }}$ century. They added to the sense of backwardness, humiliation, impotence, and loss of self-esteem, with the resulting hostility aimed against local regimes that had failed to respond to the need of their societies, as well as against the superpowers and the West in general. Muslims of all classes and ages turned to go back to Islam for a solution (Ibid).

\subsection{Crises of political legitimacy}

Another cause is the persistent crisis expressed by the weak legitimacy of the idea of nation-state as well as of the existing secular regimes. This crisis is evident in the pervasiveness of autocratic regimes and in the continuing segmentation of society along tribal, ethnic, and religious lines. The political, social, and economic failures of the secular state is seen as an important contributor to the rise of Islamic movement as a mass-based response demanding radical change. Islamists tend to blame the modern secular nation-state and its Westernized elites for the entire problem faced by the society.

Therefore, these and many factors are the genesis or environmental factors that influenced many Islamic revivalists not only Mawdudi, but all of them. The reformist came as a response to these milieus of the Muslims Ummah; they want to revive the Ummah to the real teaching of Islam and to establish government based on Islamic principle. Two particular important events served as catalysts that motivated Mawdudi to assume an independent role as an Islamic leader and attempt to be a spokesman for an Islamic alternative for state and society. In 1925 Swami Shradhanand leader of the Hindu revivalist movement was assassinated by a Muslim 
extremist who claimed it was a religious duty to kill non-believers. After the killing there was public controversy in which Islam was regarded as a religion of war. So Mawdudi came in order to defence Islam. He wrote a series of articles that were published as a book, the book that we have mentioned earlier War in Islam in 1927. He comprehensively discussed the Islamic attitude towards Warfare and also presented many themes. The second reasons that influence Mawdudi movement were the issue of Indian Independent Movement especially the question of Indian or Muslims nationalism. Mawdudi was very critical about the idea of nationalism led by Gandhi led congress party and Jinnah Muslim League.Moreover, he is aware of the political circumstances of India, and put more concern about the survival of Muslim identity and their way of life in a Hindu dominated secular state. In 1947, after the partition of Indian sub-continent into India and Pakistan, Mawdudi migrated to Pakistan and devoted all his life in producing books and pamphlets on various subject and issues and put all his effort in order to make Pakistan real Islamic state which is denied by the secular leaders of that time.

\section{Aims and Objectives of Jama'atu Islami}

- Da'awa, Jama'at Islami undertakes Da'awa activities in order to call people into the religious of Islam (the concept of monotheism).

- Enlighten the Muslim Ummah through the comprehensive teaching of Islam impact on individual and collectiveness.

- Jama'atu Islami undertakes community issues, such as protecting the safety and security of the Muslim Ummah.The pay more attention to its organizational goals and leadership at all level

- They put more concern about the protectionof religion, cultural identity, educational advancement, economic growth, correction of moral values, freedom from economic subjugation, cultural imperialism as well as liberation from despotic rule.

- On national and global issues;Jama'atu Islami calls for the establishment of equity and justice in the country.Protection of human right, attainment of social, economic, and political justice,

- Tarbiyyah; Jama'at make an effort for the refinement of their capabilities purification of soul,service to humanity, they work for the eradication of poverty, sickness, illiteracy, hunger and deprivation.

Therefore, these objectives played a significant role in educating and enlighten the society about the real teaching of Islam as a complete way of life. It was operated especially in Lahore and Pakistan. However, in the first place the Jama'atu Islami movement was formed in order to reforms the society against western ideologies, it does not have any political linkages, but when times goes on the movement metamorphosed into political party and participated actively in political activities especially in Pakistan and Bangladesh. These are some of the changes that were experienced and the movement was peaceful rather than violent, it has social relations with the people and contributed a lot in terms of welfare and taking care of the people.

\section{Methodology of Jama'at Islami}

- The Quran and the Sunna shall form the basis of all the Jama'at Islami activities. All other things shall be kept in view secondarily, and only to the extent to which these could be accommodated in accordance with the Quran and the Sunna.

- In all its actions the Jama'at Islami shall be bound by moral limits and shall never adopt such means or ways which are against truth and honesty or through which may come about communal hatred, class struggle and Fasaad.

- For the achievement of its Objective the Jama'at Islami shall adopt constructive and peaceful methods; that is, it shall reform the mental outlook, character and conduct through propagation (of Islam), instruction and dissemination of Islamic ideas, andthus shall train the public opinion in order to bring 
about the desired righteous revolution in the social life of the country.

6. Ideas, Symbols, Values, and Ideologies of Jama'atu Islami Islam the true monotheistic religion on Earth Islam is the ideology of the Jama'at Islami. Its structure is based on its belief on the three-fold concept of the Oneness and sovereignty of Allah (Monotheism), the Concept of Prophet hood and the Concept of Life after Death. From these fundamentals belief, then followed with the concepts of unity of all mankind, the purposefulness of man's life, and the universality of the way of life taught by the Holy Prophet (SAW).

\subsection{Oneness and Sovereignty of Allah}

Jama'at Islami believes that this world and everything that is in it has been created by the one God. He alone is the Creator and Sustainer of life in all its forms. Not only this; He is the Ruler and the Sovereign, and Omniscient, possesses the sole prerogative, absolute privilege andunfettered right of giving laws to mankind, through Prophets, to regulate the entire everyday activity of man. He has bestowed upon man all faculties and powers, and provided for his needs in the form of goods and services. It is, thus, the duty of man, who is the vicegerent of God on earth, that he should not only worship God but also live his whole life according to His Law and render allegiance to Him, the Lord and the Sovereign.

\subsection{Unity of Man}

Since all men have been created by the one God, and owe allegiance to Him alone, they are all equal subjects and servants of the Lord. There is no superiority in race and blood. Whoever is God-fearing, pure and pious is the best. Differences of region, race, colour and language do not divide men into separate entities; their essential oneness remains intact. Artificial divisions, geographical or otherwise, are mere matters of convenience. They should not be allowed to stand in the way of mutual understanding, respect and cooperation between man and man. Besides, as the children of Adam (peace be on him), all men belong to the same Family and all are brethren.

\subsection{Prophetic Hood}

True guidance as to how to live in this world is among the basic needs of human being. Allah has provided for every need of man, has not been indifferent to this most pressing need of man. For this purpose, since the dawn of creation, He sent His Messengers, Prophets and Apostles, to guide man to the true way of life. These Messengers appeared at different stages of human history and in different regions of the world. Everywhere they preached the same Message. The Last Messenger of God who bore the Guidance in its most complete and final form was Prophet Muhammad (Peace be Upon Him).

\subsection{Life after death}

Life does not end on this planet. This earthly tenure is not the final phase of the human adventure. On the Resurrection Day, man will have to appear before God and render an account of his conduct in this world. He will be rewarded or punished accordingly.

\subsection{Purposefulness of Man's Life}

Life on earth is to be so organized as to lead to the good of the Hereafter. While worldly life is transient, that of the Hereafter is eternal, and reason demands that the transient should be dedicated to the welfare of the eternal.This does not imply a renunciation of worldly goods and the avoidance of earthly enjoyments. What it calls for is a balanced and harmonious realisation of all the urges of man, material and mundane, as well as moral and spiritual. The Divinely revealed way of life alone enables man to attain this balance and harmony.

\subsection{Islamic Conception of Religion}

Such, in brief, are the answers that Islam gives to man's fundamental questions. Now these answers are not mere abstractions that cease to be of utility the moment they are arrived at. They afford us an understanding of the ends and values of existence, and provide a comprehensive pattern of behaviour.This pattern of behaviour, 
contrary to popular belief, includes all the aspects of life, the moral and spiritual, as well as the mundane and secular. Islam is not simply a collection of religious rites and rituals. It is concerned with the overall approach of man to life in all its multiple aspects. The concept of the Hereafter is vital to the Islamic system. But it is only through life on this planet that one attains the Hereafter; and Islam desires to convince human beings that only by a proper ordering of the whole of life on this planet in conformity with the divine guidance people can realise their spiritual ambitions. It is generally admitted that the nature of man's response to his cosmic surroundings has a profound influence on his entire behaviour. Since Islam determines this response by means of the answers that it provides for man's questions regarding the nature and destiny of man and his place in the Universe, it can hardly afford to remain indifferent to the pattern of behaviour that grows out of this response.

6.7 Islam as a complete way of life

The principles of Islam relating to the various aspects of life are of two kinds. In certain spheres of life the guidance of Islam is in the nature of certain guiding principles or directives, which presuppose not so much any precise pattern of behaviour as an attitude or spirit. They may be considered fundamental dictates on the basis of which every age can raiseits structure of life according to its needs and requirements.Thus, the verse of the Qur'an: "Their decisions are taken after mutual consultation" bears the spirit in which Muslims should approach the problems of polity. So long as the spirit of mutual consultation, which implies discussions, deliberations and advice, is present, Islam does not insist on anyone particular form, but leaves it to the discretion and good sense of its believers to adopt whatever form historically suits their needs, and also conforms to the overall spirit of the Islamic system. In certain other spheres of life, the Qur'an does not merely inculcate an attitude or a spirit, but embodies it in a definite form, thus eliminating the possibilities of multiple interpretations. Therefore, in trying to reform the society Mawdudi's played a significant role in calling the people toward Islam and contributes in educating the Muslim Ummah to the real teaching of Islam through Qur'an and Sunna. He emphasizes the need of reforming the corrupt behaviours of the Ummah through the teaching of Islamic ideologies and moral values.

Moreover, he presented Islam in its original, pure, plain and everyday language that appealed the mind and heart of the people without engaging in philosophical jargons and abstract ideas. The style he adopted was so strong, rational and impressive that it captivates the readers. He drew examples from day to day life, which naturally convinced the people to his views. He did not produce a new brand of Islam. He removed false imaginary obstacles between the Creator and mankind. He brought people close to their Creator. He presented a pure and holistic image of Islam free from all kind of distortions, Jahiliyya images and superstitious beliefs.

Sayyid Mawdudi presented Islam as a complete code of life. It is a way of life, a culture and civilization that captivates peoples' hearts and convinces their minds easily. It encompasses all aspects of human life. He systematically presented Islamic political system, economic system, cultural system, social system, ethical system and so on. He uprooted the confusion that Islam was but the name of some scattered teachings. He underlined the fundamental principles for most of these aspects based on the Qur'an and Sunnah. He urged that a Believer in Islam should accept it as a whole. Accepting some part of Islam and rejecting some others is a sheer hypocrisy and perversity. Allah says in the Qur'an:

"Then is it only a part of the Book that ye believe in, and do ye rejects the rest? But what is the reward for those among you who behave like this but disgrace in this life? - And on the Day of Judgment they shall be consigned to the most grievous penalty. For Allah is not unmindful of what ye do." Q2: 85

\section{Leadership, organisation and mass mobilisation}

- The Council of Representatives is elected by members for a period of four years.

- The Council of Representatives elects Amir of Jama'at Islami.

- The Central Advisory Council comprises 18 members elected by the Council of Representatives and 
one Secretary General, ex-officio.

- Amir of Jama'at Islami appoints Vice President, Secretary General and Secretaries in consultation with the Central Advisory Council.

- Zonal Amirs are appointed by Amir in consultation with the Advisory Councils of respective zones, keeping in mind the opinions of the members of the zone and the interest of the Jama'at Islami.

- Zonal Advisory Councils are elected by the members of the respective zones.

- Local Amirs are appointed by National Amirkeeping in mind the views of the members of the respective locations, the opinion of the Zonal Amir and interest of the Jama'at Islami members.

- National Amir makes the regulations for District and Area Organisation set-up in consultation with the Central Advisory Council in accordance with the provisions of the Constitution of the Jama'at Islami. District and Area Organisers are appointed by the National Amir in consultation with Zonal Advisory Councils and Zonal Amirs

The Islamic movement founded by Allama Mawdudi gained greater support from the people as a result of good social relations and contribution of the movement towards the reforming the Ummah and providing social welfare. The Jama'at Islami like Muslim brotherhood in Egypt spreads widely within a short period of time it covers countries like India, Pakistan, Bangladesh and others. The people supports were seen by voluntary joining the movement with their total submission and acceptance with the ideology, aims and objectives of the movement. They expressed their happiness and hope for better society whose follows the teaching of Islam.

\section{Al Mawdudi's Political Thought}

Mawdudi's Islamic political Thought was constituted based on four basic principles; The first principle of Mawdudi's thought, was a concrete comprehensive presentation of Islam as a complete way of life, which encompasses all aspects of life, individuals, groups, and it also deals with political, economic, and social aspects. The second principle is that the purpose of the meaning of life is nothing but to serve or worship Allah (S.W.T). In the third principle Mawdudi never perceived Islam as the static religion, to him Islam is a complete and dynamic whenever there is problem which were not found in Qur'an and Sunna he use Ijtihad to find the solution of the problem. The fourth principle argued that all the injustice, chaos and problems that are prevailing in political, economic, social areas of life are due to the domination of man by man in different forms. Man in this world would continue to experience all kinds of injustice as long as he does not withdraw himself from dominating others or being dominated by others through his own laws and authorities. Most of the Mawdudi's arguments were based on the Qur'an and Sunna.

\section{Mawdudi's conception of Islamic state}

Before explaining the concept of Islamic state by Mawdudi, it is very significant to clarify what that Islamic state means; according to him an Islamic state does not mean a state that are predominantly Muslims rather it is a state where the whole Islamic political system was established with all its institutions through the operationalization of the concept of Shura and where the whole shariah is implemented and fully protected. Hence the state in Islam is not an end by itself rather a mean to an end submission to all injunctions of Allah (S.WT) and Prophetic traditions to win the pleasure of Allah. The right of the non-Muslims in an Islamic state should be protected as long as they abide with the conditions laydown by Islamic state and they have to pay the Jizya.

10. The Philosophy of an Islamic state by Mawdudi

\section{First is the principle of an Islamic state}

According to him the principles of Islamic state was based on three creeds Tawheed, the Onness of Allah, Risalah, the Prophet hood and khilafah the man's Vicegerency on earth. He argued that these three principles form the foundation of an Islamic state. An Islamic state cannot be established without any of these three 
principles. Tawheed underlines that Allah (SWT) alone is the Creator, Sustainer, and Master of the universe and that $\mathrm{He}$ alone commands obedience from all aspects of life individually and collectively. Moreover, he viewed that the sovereignty belongs to Allah alone, He is the real Sovereign. The second creed Risala Prophetic hood according to Mawdudi is the medium through which we have received the message of Allah, the two important sources of the Laws of Allah (Shariah) the Qur'an and the Prophetic traditions. The third creed Khilafah, man is the Vicegerency or representative of Allah on earth, man possesses limited authority which is delegated to him by Allah and he obliged to administer in accordance to the instruction of Allah (SWT).

Further, he asserted that sovereignty belongs to Allah alone because He alone possesses the attributes of Sovereign. Mawdudi backed his argument base on five basic observations as follows; Allah can do whatever He likes, $\mathrm{He}$ is not accountable to any one, nor Has He refer to any one, He is the sources of all authority, His authority and Power is limitless, and He is above all limitations and errors.

Secondly, the Purpose of an Islamic state and its characteristics

Mawdudi's views on the purpose and characteristic of an Islamic state centred on the above mentioned factors, Allah's sovereignty, man's Vicegerency, and Sharia's supremacy. He cited the following verse of the Holy Qur'an to highlight the purpose of an Islamic state:

"Muslims are those who, if We give them power in the land, they establish the

System of prayer (Salat) and poor due (Zakat), and enjoin virtue and forbid

evil and inequality. "Q23:41

Mawdudi explained vividly the above following verses, according to him iron symbolises political power. Allah (SWT) sent His messengers and the Scriptures to provide guidance to mankind. Allah also blessed His vicegerents with the political power in order to established justice. They are the ones who establish the system of Salat and Zakat and also forbid all kinds of vices and promote virtues, Mawdudi also elaborated on the characteristics of an Islamic state.

According to him, an Islamic state is universal and all embracing; it is ideological, since Islam encompasses all aspects of life, and Islamic state is coextensive with the whole of human life. Islamic state maintains the balance between the interest of an individuals and the collective interest of the society. As an ideological state, Islamic state is based on the principles, not on racial, lingual, geographical, and such other principles. Hence, all those who wish to stay in an Islamic state are welcomed and they would be protected without any kind of discrimination. Moreover, with regard to the issue of loyalty in an Islamic state, Mawdudi opined that loyalty was based on three principles; Allah alone is the centre of loyalty, then loyalty and obedience to the Prophet (SAW), and obedience to Ulul Amr, those who are in the authority in government but subject to the conditions in which their policies should be in line with the spirit of the Qur'an and Sunnah.

\section{Thirdly, directive principles of state policy (Manifesto of Islamic State)}

Mawdudi viewed directive principles of an Islamic state policy based on the Qur'anic injunctions. He derived these principles from Qur'an which were revealed to the Prophet Muhammad (SAW) on the historic occasion on the eve of Madinan period. He mentioned twelve principles of an Islamic state as follows:-

None should be worship except Allah, Right of Allah and His Prophet, Right of parents, relatives, needy and destitute. There should be a healthy economic system that can establish justice and maintain fair distribution of wealth, No abortion in Islam, he rejected family planning, Adultery and all forms of fasad it is immoral and it should be prevented, Slaying of human life is the greatest crime in Islam, Foreign policy agreement made by an Islamic state with the other state should be respected and not be broken, Islamic state should check malpractice and exploitation in the economy, It is not permissible for an Islamic state to take actions based on suspicion, and lastly, the lives of those in a position of authority should be free from arrogance and pomp show rather courtesy 
and kindness should be their ways.

\section{Mawdudi's Organs of Government in Islam}

According to him the organs of government should be divided into three as follows:-

Shura/Parliament had the responsibility of making laws based on Qur'an and Sunna it must consist people who are knowledgeable Ahl al-Hall wal 'Aqad. Another organ is Amara/Executive had the responsibility of execution or implementation of law based on Islamic principles and they should secure directives from Allah (S.W.T) and rules according to Qur'an and Sunna. The last organ of government in Mawdudi's thought was Qada/Judiciary that had the responsibility of interpreting the law, this consist of judges which they must exercise their function in line with Qur'an and Sunna. They have to follow what was revealed by Allah (S.W.T). Mawdudi accepted the clear separation of power between these three organs; each organ must be independent and answerable to the chief of the executive who is the head of state and he too is answerable to Allah.

\section{Election of the Head of State}

After chronological survey of all the model of selection and election of the four rightly guided Caliphs by Mawdudi, he came out with the following point of views:-

- The election of the head of state mainly depends on the will of the general public. A person who expresses his aspirations for any position is not eligible for the position.

- No clan or class can claim the monopoly of the office of the head of state;

- Election should be conducted on the basis of free will of the masses without any force or coercion.

Regarding to the members of legislative (Majlissu-Shurah) he maintained that the people should look at some specific persons who were entrusted due to their methods of appointment and consultations. He pointed out that during the period of Caliphate; there were some people who have knowledge and wisdom, which could be called "Ahl al Hal wal Aqd". The caliphs used to consult such persons in all important matters. This practice of the Caliphs was based on the Prophetic traditions of consultation concerning matters that affect the common good of the Ummah.Mawdudi outline some conditions for choosing a leader and who ever want to be a leader must possesses such qualities as follows; The person should be a Muslim, Male, Adult and sane, and citizens of an Islamic state.

\section{Mawdudi on Citizenship in an Islamic State}

Mawdudi identified two types of citizenship in an Islamic state; the Muslims and the non-Muslims (Ahlul dhimmis). He argued that the Muslim citizens must perform all the socio-political directives of the state. They are vested with many obligations and sacrifices in order to defence the state. They enjoy the rights of choosing the head of state, membership of law making bodies, and appointment of the key position in an Islamic state. Whereas, the non-Muslims enjoy civil liberties and protection with the condition of paying the tax (Jizya) and within the non-Muslim women, children, elderly and disable people were exempted for paying the tax.

\subsection{Rights of Citizens in an Islamic State}

Security of life and properties, Protection of Honour, Protection of sanctity of private life, Place of worship should be protected, Riba is haram in Islam, Freedom of speech and association, Islamic state should not promote tyranny, Protection of religious sentiments of all communities, Provision of basic amenities for life, and Equality before the Law, Rulers are enjoined to follow the Islamic law, Freedom to participate in the affairs of the state in accordance to their eligibility.

\subsection{Rights of the Non-Muslim citizens (Dhimmis)}

Rights to life, the Islamic state should protect the life of the Dhimmis as long as they abide with the condition laydown by the Islamic state and they are paying Jizya. The Muslims and the Dhimmis are treated under the panel laws, Muslims should refrain from causing injury, abuse, assault, or even any inconvenience to the 
Dhimmis. All personal matters including marital affairs of Dhimmis are to be settle by their own personal laws, Dhimmis are allowed to perform their religious rites, and festivals with full freedom in their own localities. In purely Muslims areas, dhimmis are not allowed to build new places of worship. Coercive or violent methods are prohibited in the realization of Jizya and Kharaj. Dhimmis are exempted from military services because these responsibilities are entrusted to Muslims alone.

It is quite obvious from the above that Mawdudi's reflections of an Islamic state, government and citizenship are based on Qur'anic injunctions and Prophetic traditions. There is no doubt that during the virtual establishment of an Islamic state in any part of the world and its virtual functioning in contemporary times, there would be a need to elaborate some more on the principles, structures and functions of an Islamic state. However, it cannot be denied that the philosophy of the Islamic state and the broad principles that guide its structure and functions are clearly outlined by Mawdudi. Now, it depends on contemporary Muslim scholars and leaders to work for the actualisation of an Islamic state and elaborate its details in the light of contemporary situations.

\section{Programmes of Jama'atu Islami}

The Jama'atIslami regards Islam as the authentic way of life revealed by the Creator of the universe; for all human beings. Accordingly the invites all people towards submission to God (which is the literal meaning of Islam).The first major point of its programme is an intellectual one that is a clear exposition of the teachings of Islam which is shorn of all false ideas and eliminated of all unhealthy ideologies. This exposition is geared to showing how the teachings of Islam can be applied in the present day world, and what steps should be taken so as to develop a sound and healthy order of life. This necessitates' a stock-taking both of the Muslim heritage and of modem civilisation, followed by a discriminate appropriation of healthy elements from them. So far as the teachings of the Qur'an and the Sunnah (model of the Prophet) are concerned, they are eternally binding and should, thus, be followed in all periods of history.

It is an undisputable fact that the present Muslim society has lost a great deal of its original dynamism and clean because it has lost sight of the original order of priorities, that is, the Qur'an, the Sunnah and the Opinions of the scholars. The Muslims have almost reversed this order. They now turn, in the first place, to the opinions of the scholars of the past. It is only after looking into their opinions that they turn to the Qur'an and the Sunnah. This has stultified the Muslim mind. The original dynamism can be recaptured only if the Muslims decide to replace the present by the original order of priorities. This means that they ought to look first to the Qur'an, then to the Sunnah, and after that to the deductive elaborations of the scholars and to the ideas propounded by Muslim thinkers.

Another effort of the Jama'atu Islami is to reach out to the persons who are disposed to righteousness, and are inclined to work for the establishment of righteousness in human life.Such persons should be identified and brought together into an organised body. Not only that, an effort should also be made to help such people develop a clear outlook to purify their lives and cultivate the qualities of good moral character in them. It is only after a group of people, which combines true Islamic vision and Islamic character side by side with intellectual competence and with the skill needed to run the affairs of this world, emerges on the stage of human history, pools its strength and resources, and strives in a systematic manner that God will permit the Islamic Order to be established. This group, however, is not to remain stationary. It should rather expand by persuading others to share its viewpoint and cooperate in the struggle to establish the supremacy of justice and righteousness.

Moreover, one major significant item of the programme consists of striving to bring about societal change and to effect reform in the light of Islamic teachings. The idea is that the people who are dedicated to the cause of Islam, or at least have an Islamic orientation and a concern for the well-being of human society, should take the initiative and expend their time, effort and resources to bring about maximum healthy change and improvement. 
This programme of societal reform is quite a comprehensive one. It seeks to make the mosque the hub of all Islamic activity.

Further, there is heavy emphasis on education: the basic teachings of Islam should be communicated to the common people, arrangements should be made for adult education, reading rooms should be opened to create enlightenment, and educational institutions should be established at different levels. In the area of social life, the programme emphasises resort to public pressure to prevent people from being subjected to injustice; creating a sense of hygiene and cleanliness and fostering cooperation among people so as to ensure healthy conditions of living; drawing up lists of orphans and widows, of the crippled and the incapacitated people, and of poor students and arranging for their financial assistance; and catering for the health requirements of people, especially the poor. Clearly, inspired by Islamic ideals, the objective is to foster the religious, moral, social and material welfare of thepeople and to move towards creating the social conditions which are conducive to the total transformation of human life.

The Jama'at Islami also envisions changes of leadership in the broadest sense of the term. It includes intellectual leadership, social and cultural leadership, and ultimately, political leadership too, which marks the culmination of the process. The state is conceived as an indispensable means for establishing the order envisaged by Islam. A truly Islamic state is considered inconceivable unless its affairs are directed by people of clear Islamic vision and commitment, and upright character and competence.As far as non-political leadership is concerned, the change can be brought about by developing leadership qualities in people who are possessed of right orientation. This is one of the aims of the Jama'at Islami. As for the change of political leadership in today's world, this can be brought about by educating the public opinion and channelizing it. Jama'at Islami provided a formidable ground for the Islamic movement not only in Asia, but around the worldwhich is hopefully that if the Islamic movement keeps on striving patiently, it will ultimately succeed in installing righteous men in power.

\section{Political significance of the activities}

The political significance of these activities can be seen through the support and mobilisation gained from the people as a result of welfare programmes provided by the movement. The movement contributed in many aspects economically, socially, culturally and politically through enlightment campaign and education. The sources of income for Jama'at Islamic activities can be secured through membership dues and donations also contribution from Islamic organization from Saudi Arabia. Jama'at Islami Political activities can be seen through fully participation into the political arena for the power struggle in order to win the election and establish real Islamic government. They joined political parties, participated in campaign, rallies, and seminars in order to have peoples mandate but the government humiliated them. With regard to the social activities, we have already mentioned earlier they played a significant role in building schools, hospitals, orphanage home, taking care of orphans and widows, provisions of basic things to needy and destitute and others.

\subsection{Problems faced by Jama'at Islami}

There is no achievement without some problems especially in an organisation or movement like that of Jama'at Islami. The problems faced by the movement are as follows:

- The political system never allowed the Jama'at Islami to establish itself as a powerful political organisation; they metamorphosed into political parties and participated actively in an election in Pakistan but were suppressed by the secular leader.

- The Jama'at Islami was unable to follow its master frame because they were supposed to build up a group of trainers who will educate the population on Islam and its ideology but instead they quickly joined politics which generated many problems with regards to the objective of the organisation.

- The decision of Jama'at to enter politics may be regarded as a mistake because any social movement 
that enters party politics cannot achieve its main goal.

\subsection{The relationship between Jama'at Islami and Pakistan Government}

Generally speaking, as far as Jama'at Islami there was no mutual relationship with the government instead hatred and suspicion, government threating to suppressed the movement by any means in which many its leaders were imprisoned including Mawdudi himself. There was a time in which Mawdudi was sentenced to death but later was imprisoned and released. Mawdudi's ideology which is based on Islamic teachings and Shariah does not compromise that of the government he regarded Qur'an as his constitution and all members of Jama'at Islami. $\mathrm{He}$ is always against capitalism, socialism and viewed them as a man-made ideologies that are not capable of bringing any positive changes in the society rather exploitation and stagnation. In later times, Jama'at Islami joined political parties and participated actively in the struggle for power but was suppressed by the secularist leaders due to their rejection of western system of democracy and calling for the implementation of real Islamic Shariah. Hence, these are the factors that led to the failure of their political struggle, not that they are not gaining the support of the people rather were supressed by the government.

\subsection{Radicalism and violence}

Jama'at Islami was a peaceful movement formed with the aim of transforming the societal moral values through peaceful means not through violence. Mawdudi differed from the tradition that considers violence as a defining characteristic of revolution. His main point of divergence from that tradition lay in his conception of evolutionary process. He is totally against all unlawful, unconstitutional, and subversive acts and distrusted political radicalism of any kind. Respect for law and order was indispensable to the civilised society and hence he cautioned the revolutionaries to resist the temptation of resorting to the methods and techniques of secret movements and bloody revolutions. Moreover, Mawdudi did not believe that anything positive could result from disrupting the social order. Creating disorder is against wish of Allah. Islamic movement is for the cause of Allah and it should be conducted openly and peacefully even at the risk of courting hardship and miseries. Therefore, Jama'at Islami operated peacefully without any violence despite the fact that most of its members and leaders were torched and humiliated but this would not make them to be violent organisation and react violently.

\subsection{General Lessons of Jama'at Islami movement}

One of the greatest lessons derived from Mawdudi's Islamic movement was operating under peaceful umbrella without the element of radicalism and violence approach. He provided a good examplinary manner of knowledge theoretically and practically, he tried to implement what he taught in practice. He challenged the other revolutionary movements that are operating underground without social relations with the people, also cautioned them about their revolutionary approach. According to him revolution is a process of comprehensive and fundamental changes in the system which requires first and foremost, changing the man himself, his outlook, his motivation and his personality. In one of his speech he opined that" Whatever I have done, I have always done it openly within the boundaries of law and existing constitution, so much so that I have never violated even those laws which I have fought hard to oppose. I have tried to change them through lawful and constitutional means and never adopted the path of violation of the law."

Another lesson derived from Mawdudi's movement was societal transformation through the teachings of real Islam as a complete way of life. He tried to reform the educational system by Islamizing the western knowledge of science and humanities to bring them into the line of Islamic teachings. Mawdudi emphasize the need for critical evaluation and assessment of the both the Muslim heritage and Western science. He urged that the Muslim heritage be analysed against its historical background and if the legacy is found to be inadequate or erring, the terms of the divine status of the Qur'an and normative Sunna and their relevance to the problems of the present should be corrected. In a nutshell, Mawdudi proposed educational reforms for secondary, higher 
secondary and university levels. His emphasis was on the university level for which he spelled out the modality for the implementation of his reforms. Reform propounded by Mawdudi found its practical manifestations in the 1980s in many part of the Muslim world especially in the International Islamic University Islamabad and International Islamic University Malaysia (IIUM) founded in 1983.

Apart from contribution towards the transformation of education, Mawdudi's movement played a significant role in establishing mutual relationship with the people through its activities which are related to welfarism and humanistic issues. The movement contributed in helping the needy, destitute, orphans and widows. They also established clinics, schools, and charitable unity that are assisting people who were engulfed by disasters and calamities. Jama'at Islami united the Muslim Ummah under the banner of Islami; it remoulded the moral values of the society to in line with the Qur'anic teachings and Sunna of the Prophet (SAW).

\subsection{Contributions of the movement to Islamic reform and revivalism}

Jama'at Islami contributed to the emergence of other movement around the world as a result of its approach and methodology in dealing with the society and government, and one important thing is peaceful evolutionary approach of transforming the society towards the real Islamic teaching and going back to the authentic Islam as delivered by Prophet Muhammad (SAW) and his companion. Jama'at Islami serves as a formidable ground for the emergence of many Islamic reforms such as, Al-Nahda movement in Tunisia led by Rashid Ghannouchi, Hassan Al-Turabi in Sudan, the leader of National Islamic Front, Muhammadiyyah movement in Indonesia among others. Jama'at Islami also contributed to the emergence of new Islamic oriented elites seeking to implement Islamic alternatives in society along two lines: preaching the (da'awa) to convert and transform individuals to Islamic practice in daily life, and the creation of Islamic spaces in society Islamic neighbourhoods, schools, clinics, banks, and mutual-aid networks.

Their success can be seen in the domination of Islamic treatises in the media and in the public sphere, in the adoption of Islamic dress, the segregation of the sexes, the rise of Islamic banking and economy, the free mosques, the Islamic domination of professional associations and student unions, and in the great number of Islamic organizations active in welfare and education. Example of these new generation thinkers are Muhammad Salim Al-Awa an Egyptian born scholar, Fathi Osman also from Egypt, Murad Hofman German scholar, Abdulaziz Schedina from Tanzania, and Abdulkarim Soroush from Iran among others.

\section{Conclusion}

Mawlana Abu A'la Al-Mawdudi is great a significant figure in the contemporary Islamic movement, an Islamic scholar, philosopher, thinker who contributed extensively towards the propagation of Islam and unity of the Muslim Ummah under the banner of Islam. He wanted to see the establishment of an Islamic government but his dream didn't came into reality, he died in the year 1972, and leave a greater legacy in the reformation and revival of Islam in the Indian sub-continent and other part of the Islamic World.

\section{References}

Abu-Rabi, I. (2004) Contemporary Arab Thought: Studies in Post- 1967 Arabs Intellectual History; London Pluto Press.

Deukmejian, R. H. (1985) Islam in Revolution: Fundamentalism in the Arab World; Syracuse, N.Y. Syracuse University Press.

Esposito, J. L (1984) Islam and politics, Syracuse university press, Syracuse New york.

Hassan, M. (1984) Sayyid Abul A'la Mawdudi and his Thought, Lahore: Islamic Publication Ltd $1^{\text {st }}$ edition, Vol. 2.

Moten, A. (2006)Islamic thought in contemporary Pakistan: the legacy of Allama Mawdudi $\quad$ Abu- Rabi. I.M. (eds) The Blackwell companion to contemporary Islamic Thought.Blackwell Publishing. 
Tibi, B. (2000) The Challenge of fundamentalism; Political Islam and the New World Disorder, updated edition Barkely.

Ushama, T. \&Osmani, M.A.(2006).Sayyid Mawdudi's Contribution towards Islamic Revivalism Vol. 3. 2006.

Zeenath, K. (2005) Contemporary Islamic Political Thought: A Study of eleven Thinkers; Kuala Lumpur, Malaysia: Ampang Press.

\section{Copyrights}

Copyright for this article is retained by the author(s), with first publication rights granted to the journal.

This is an open-access article distributed under the terms and conditions of the Creative Commons Attribution license (http://creativecommons.org/licenses/by/4.0/). 